\title{
TERRITÓRIO, MERCADO E ESTADO: UMA CONVERGÊNCIA HISTÓRICA
}

\author{
MÓNICA ARROYO \\ Universidade de São Paulo
}

A convergência de território, mercado e Estado é um processo histórico e, ao mesmo tempo, conceitual, perfeitamente datado. Este artigo busca indagar a forma em que essa convergência se desenvolveu no continente europeu para, por fim, chegar aos territórios coloniais e refletir, em particular, sobre a América Latina.

\section{Território e Estado, as origens}

Se pensarmos o "território" como um conceito que supõe o exercício do poder e que implica um processo de apropriação, de delimitação e de controle, estamos enfatizando, sem dúvida, sua dimensão política. E se, além disso, pensamos na legitimidade desse poder e, portanto, na idéia de soberania, estamos cada vez mais próximos de sua dimensão jurídica. Por sua vez, a dimensão político-jurídica do território está associada à existência do "Estado" como a instituição que detém o poder de soberania, ou seja, controle exclusivo de um âmbito geográfico definido. Chegamos, assim, à idéia de território do Estado ou de Estado territorial.

Desde a conformação do sistema interestatal moderno, o Estado territorial é a unidade primária e principal da política internacional; daí que o mapa desse sistema esteja composto pelos territórios dos Estados, delimitados por fronteiras que são o resultado do exercício da soberania. Esse mapa político mundial está atualmente subdividido em mais de duzentos territórios estatais. Mas quando e como começou o processo de associar território e Estado?

O termo território foi aplicado no início às cidades-estado do mundo clássico para designar a zona que circundava uma cidade e que estava sob sua jurisdição 
(GOTTMAN, 1973). Aplicou-se, mais tarde, às cidades medievais italianas. Todavia, os territórios das cidades clássicas e medievais não eram soberanos. A união entre território e soberania surge, séculos mais tarde, como resultado da dissolução do regime feudal e da erosão do poder temporal da Igreja. Trata-se de um longo processo que se estende desde 1494 - quando da invasão das cidades-estado italianas pela França e depois pela Espanha - até o tratado de Wesfália em 1648, fim das pretensões de universalidade do império e do papado. É nesse período que se perfila a configuração dos Estados territoriais soberanos.

O Tratado de Westfália de 1648 traz a primeira base legal do sistema interestatal moderno, já que reconhece a soberania de cada Estado no seu território e implica a obrigação de não interferir nos assuntos internos de outros Estados. A soberania territorial transforma-se, assim, em uma atribuição do Estado com relação ao controle exclusivo de um âmbito geográfico definido. Dessa perspectiva, o território torna-se uma categoria do direito internacional.

Conforme Peter Taylor (1994), os Estados territoriais definem-se em termos de um "dentro" e de um "fora": por um lado, relacionam-se com a sociedade civil e as atividades econômico-sociais existentes dentro de seu âmbito; por outro, cuidam das relações com o resto do sistema interestatal. A extensão geográfica de sua jurisdição e sua posição associam-se a aspectos importantes das relações exteriores, como proximidade, contigüidade, distância e acessibilidade. Essa concepção do exercício da soberania territorial começa a se espalhar gradual e lentamente, através dos continentes, como o modelo dominante de organização política.

As funções básicas do Estado territorial, segundo Jean Gottman (1973:52), são segurança e oportunidade. A primeira relaciona-se com as origens políticas do sistema interestatal e a segunda com a formação do incipiente mercado mundial:

A soberania tinha sido interpretada com demasiada freqüência como função da regulação do poder, e especialmente do poder político. Na administração do território, contudo, a soberania tinha de lidar com os recursos e os serviços econômicos, com a gestão dos modos de vida e com a melhoria e o desenvolvimento, assim como com a regulação, a limitação e a prevenção. Os deveres e responsabilidades do soberano tinham sido essencialmente politicos, religiosos e militares até o século XVI. Com um mundo em expansão abrindo-se diante de um numero crescente de Estados soberanos, novos propósitos de governo foram passando ao primeiro plano no reino econômico. As características do território e seu uso iam adquirindo um novo significado.

A partir da proposta de Gottman, poderíamos pensar que, pelo lado da segurança, o território aproxima-se do Estado e que, pelo lado da oportunidade, o território relaciona-se com o mercado. Mas a associação entre território e mercado começá nesse momento ou é anterior? 


\section{Território e mercado, as origens}

Na realidade, se seguirmos a interpretação de Karl Polanyi (1944:73), o ponto de partida para pensar o mercado poderia ser a obtenção de bens distantes, como numa caça: "A aplicação dos princípios observados na caça para obter bens encontrados fora dos limites do distrito levou a certas formas de troca que nos apareceram, mais tarde, como comércio". Para esse autor, o comércio a longa distância é um resultado da localização geográfica das mercadorias e da "divisão do trabalho" dada pela localização. Esse comércio muitas vezes engendra mercados, uma instituição que envolve atos de permuta e, se o dinheiro é utilizado, de compra e venda.

Segundo Fernand Braudel (1979:12), a palavra mercado pode aplicar-se a todas as formas de troca desde que ultrapassem a auto-suficiência. Para ele "o mercado, mesmo elementar, é o lugar predileto da oferta e da procura, do recurso a outrem, sem o que não haveria economia no sentido comum da palavra, mas apenas uma vida 'encerrada' na auto-suficiência ou na não-economia".

Quando a fase de pura subsistência é ultrapassada, torna-se necessário que os excedentes de cada grupo sejam trocados. É o momento da troca simples, do escambo. Mas este tipo primitivo de comércio não tem força para mudar a forma particular com que cada grupo valoriza o tempo e o espaço. É o comércio especulativo que traz mudanças, por criar uma nova relação social com a introdução da mercadoria e da moeda. A sociedade local tem de se adaptar ao novo processo produtivo e às novas condições de cooperação (SANTOS, 1978). Não há, portanto, história simples e linear do desenvolvimento dos mercados, sobretudo porque "uma vez que a troca é tão velha como a história dos homens, um estudo histórico do mercado deveria estender-se à totalidade dos tempos vividos e situáveis" (BRAUDEL, 1979:193).

Nas primitivas fases do desenvolvimento da cidade antiga, a idéia de mercado como ponto de junção das rotas de comércio já era reconhecida. "Não há necessidade de duvidar que o mercado apareceu inicialmente para regular a troca local, muito antes que qualquer 'economia de mercado', baseada em transações tendo em vista um lucro monetário e a acumulação de capital privado, viesse a existir" (MUMFORD, 1961:85). Assim, para este autor, as duas formas clássicas do mercado, a praça aberta ou o bazar coberto, e a rua de barracas ou de lojas, possivelmente já tinham encontrado sua configuração urbana por volta de 2000 a.C.

Sem a pretensão de uma análise através do tempo multissecular, e seguindo a proposta de Polanyi (1944), podemos continuar nossa indagação refletindo sobre a natureza dos mercados, tanto locais quanto de longa distância. Para este autor, ambos os mercados baseiam-se no princípio da complementaridade:

O mercado externo é uma transação; a questão é a ausência de alguns tipos de mercadoria naquela região. O comércio local é limitado às mercadorias da região, ás quais não compensa transportar porque são demasiado pesadas, volumosas ou perecí- 
veis. Assim, tanto o comércio exterior quanto o local são relativos à distância geográfica, sendo um confinado às mercadorias que não podem superá-la e o outro às que podem fazê-lo. Um comércio desse tipo é descrito corretamente como complementar. (POLANYI, 1944:74)

Podemos pensar, então, que essa complementaridade implica uma divisão territorial do trabalho. O intercâmbio de produtos é possível porque existe uma repartição do trabalho vivo em diferentes lugares, mais ou menos próximos. IsTo pressupõe, por sua vez, a existência de certa especialização produtiva dos lugares.

Vejamos a trajetória dos mercados externos. Originalmente, o comércio exterior esteve ligado a aventura, exploração, caça, pirataria e guerra. A partir dele, os mercados se desenvolveram em todos os lugares onde os transportadores tinham de parar, nos vaus, portos marítimos, cabeceiras de rios ou nos pontos onde as rotas de expedições se encontravam. Podemos pensar no sistema de intercâmbios existentes na bacia do mar Mediterrâneo no mundo romano. Tecidos de Constantinopla, de Odessa, de Antioquia, de Alexandria, vinhos, azeites e especiarias da Síria, papiros e trigos do Egito, da África e da Espanha, vinhos da Gália e da Itália circulavam, unindo as duas grandes regiões do Império, o Oriente e o Ocidente.

O caso de Marselha, citado por Henry Pirenne (1925:19) como o grande porto de Gália até o começo do século VIII, pode ser um exemplo:

O movimento economico de Marselha propaga-se naturalmente ao hinterland do porto. Sob a sua influência todo o comércio da Gália se orienta para o Mediterrâneo. Os impostos mais importantes do reino dos francos estão circunscritos aos arredores da cidade: Fos, Arles, Tolun, Sorgues, Valência, Viena e Avinhão. Eis uma prova evidente de que as mercadorias desembarcadas na cidade eram expedidas para o interior. Pelo curso do Ródano e do Sena, assim como pelas vias romanas, atingiam o norte do país.

O comércio de longo curso também exerceu grande influência no renascimento econômico da Europa ocidental a partir do século XI, fundamentalmente sob a ação de dois centros: Veneza e Flandres. Já no decorrer do século XIII, toda a Europa, do Mediterrâneo ao Báltico e do Atlântico à Rússia, achava-se aberta ao grande comércio. Lãs finas da Inglaterra, vinhos do Reno, especiarias e sedas do Oriente, armas da Lombardia, açafrão e prata da Espanha, couros da Pomerânia, tecidos acabados de Flandres, ícones religiosos e objetos devocionais de vários centros de arte circulavam por rotas marítimas e fluviais avançando para o interior do continente. Este comércio está sempre ligado à vida urbana, com a atividade dos mercadores dinamizando o mundo dos negócios.

Pirenne (1925) atribui aos portos - "lugar por onde se transportam mercadorias, portanto um ponto particular ativo de trânsito" - um papel central no estabelecimento de cidades na Europa Ocidental. Já Lewis Mumford (1961) inverte esta 
equação, insistindo em que o comércio de longa distância não produziu cidades medievais, mas promoveu seu crescimento, como em Veneza, Gênova, Milão, Arras, Bruges, embora tenham sido fundadas para outras finalidades:

A verdade, pois, está na interpretação contrária a Pirenne: foi a revivescência da cidade protegida que ajudou a reabrir as rotas de comércio regionais e internacionais e conduziu à circulação transeuropéia dos bens excedentes, particularmente os artigos de luxo que podiam ser vendidos com altos lucros aos príncipes e magnatas, ou os artigos suficientemente escassos no suprimento local para serem pagos a bons preços. (MUMFORD, 1961:280)

Independentemente da origem das cidades medievais ${ }^{1}$, o importante é destacar sua relação com seus mercados externos e o modo como eles ajudavam a desenhar sua topologia. O comércio a longa distância permitiu que as cidades estendessem suas trocas bem além de suas muralhas, mobilizando parte importante da sociedade feudal e instalando uma tendência à ampliação do comércio que não teria retorno nos próximos séculos. Não apenas os grupos de mercadores, mas também as instituições feudais, especialmente a Igreja, interessavam-se pelo comércio:

Já no século VIII os agentes dos mosteiros franceses mostravam-se ativos em Flandres, comprando lã para manufatura. No comércio de vinho da Borgonha, eram os mosteiros os centros importantes, e as abadias no Loire e no Sena possuiam uma frota de embarcações fluviais para executar seu comércio. Na Inglaterra, o mais antigo estabelecimento de mercadores alemães parece ter sido uma ordem de monges. Os cistercienses estavam por toda parte empenhados ativamente no comércio de lã com mercadores flamengos e italianos (DOBB, 1963:105).

Claro que esse processo não foi linear, nem livre de conflitos. Por um lado, praticava-se a pirataria como se fosse uma atividade industrial; os naufrágios eram constantes; o mau estado dos caminhos tornava difícil e lento o trânsito terrestre. Por outro, a atitude dos príncipes perante o comércio nem sempre era estimuladora. Criaram-se alguns pedágios, que funcionavam como impostos afastados, a maioria da vezes, de um propósito público. “

\footnotetext{
1. Há uma controvérsia quanto ao surgimento das cidades medievais. Maurice Dobb (1963) apresenta quatro explicações existentes na literatura: a) eram sobrevivências romanas antigas, tendo mantido alguma continuidade de instituições por todo o período de devastação bárbara; b) tinham origem puramente rural, crescidas com o engrossamento demográfico em certos agrupamentos, existindo continuidade urbana entre a coletividade aldeã e a urbana; c) originaram-se de acampamentos ou das paradas das caravanas de mercadores (tese defendida por Pirenne); d) estão relacionadas com o direfto de sauveté, ou abrigo concedido pela autoridade feudal, sendo assim criações da própria iniciativa feudal para seus próprios fins.
} 
A portagem da Idade Média, usurpada pelos príncipes territoriais, tornou-se um mero direito fiscal que gravava de forma brutal o trânsito. Nem um centavo do dito imposto se gastava em reparar os caminhos ou em reconstruir as pontes". (PIRENNE, 1933: 94)

Pode-se falar, outrossim, de uma geopolítica mediada pelo comércio, na qual as cidades têm uma participação crescente. Por exemplo, com o objetivo de preservar os interesses dos mercadores ao longo da costa do mar Báltico, um grupo de cidades sob a liderança de Lübeck formou uma associação comercial, conhecida como a Liga Hanseática, que chegou a aglutinar numerosos centros urbanos. Mas as cidades não eram apenas protetoras dos mercados, eram também um meio de impedi-los de se expandirem. Segundo Pirenne (1933:149), "entre as cidades italianas, as guerras são constantes e cada uma se empenha em destruir o comércio das rivais, para aproveitar-se de sua ruína" (PIRENNE, 1933:149). É assim que "essa confederação de cidades marítimas alemãs, que oferece um contraste tão marcante com as contíguas guerras das cidades italianas do Mediterrâneo" (idem: 155), permite observar a dupla relação das cidades medievais em relação aos mercados, que elas tanto envolviam como impediam de se desenvolver.

\section{O Estado territorial, o mercado nacional}

Os mercados a longa distância e os mercados locais não diferiam apenas em tamanho, eles funcionavam separados dentro dos limites da cidade medieval. O comércio local estava sujeito a uma rigorosa regulamentação (no caso dos alimentos, era exigida publicidade obrigatória das transações e exclusão de intermediários e, no caso dos artefatos industriais, a produção era regulada de acordo com as necessidades). Desde o século XII promulgaram-se pregões e ordenanças cujos textos versavam sobre:

(...) proibição de 'recortar' os víveres, isto é, de comprá-los ao camponês antes de chegarem à cidade; obrigação de levar diretamente todos os gêneros ao mercado e expôlos no mesmo até certa hora, sem poder vendê-los a pessoas que não fossem burgueses; proibição aos carniceiros de conservar carne nos porões ou aos padeiros de obter mais trigo do que o necessário para o seu próprio forno; proibição, enfim, a cada burguês de comprar mais do que o suficiente para si e para a família. (PIRENNE, 1933:181)

Tomavam-se essas medidas a fim de controlar o comércio e impedir a elevação dos preços.

Já o comércio a longa distância não era tão estritamente regulado, fugindo bastante ao controle das administrações municipais. As grandes feiras, que desempenharam um papel de primeira ordem enquanto prevaleceu o comércio errante, são 
um bom exemplo disso: "O direito reconheceu às feiras uma situação privilegiada. O terreno em que se realizam é protegido por uma paz especial que estabelece castigos particularmente severos em caso de infração". (PIRENNE, 1933:105) Nos mercados locais, a única proibição que afetava o mercador estrangeiro era a venda a varejo, podendo participar neles somente através de corretores. Por sua vez, a produção para a exportação era apenas formalmente supervisada pelas corporações de artesãos.

A separação estrita entre o comércio local e o de exportação não permitia, por sua vez, espalhar essas práticas muito além das muralhas, impedindo a ampliação dos mercados:

Mantendo o principio de um comércio local não-competitivo e um comércio a longa distância igualmente não-competitivo, levado a efeito de cidade a cidade, os burgueses dificultaram, por todos os meios ao seu dispor, a inclusão do campo no compasso do comércio e a abertura de um comércio indiscriminado entre as cidades e o campo. (POLANYI, 1944:78)

Na prática, isso significa que as cidades fortificadas levantavam todos os obstáculos possíveis para que os negócios e o comércio se difundissem pelos territórios vizinhos.

Os mercados medievais apresentavam-se como uma série de pontos, ficando muitos vazios, à margem dos tráficos. Apesar de os mercadores organizarem ligações e constituírem linhas de troca, sua ação não chega a espraiar-se como uma mancha sobre os territórios. Não se criam superfícies mercantis contínuas: "O mapa comercial da Europa nesse período mostraria corretamente apenas cidades, deixando em branco o campo - este pareceria não existir no que concerne ao comércio organizado". (POLANYI, 1944:77) Estas cidades, que eram a expressão político-administrativa dos mercados, levantaram todo tipo de obstáculos à formação de um mercado interno: sua preocupação era assegurar o caráter não-competitivo - isto é, monopólico - do comércio municipal e de longa distância.

Até a época de Revolução Comercial, o que pode nos parecer como comércio nacional não era nacional, e sim municipal. Os hanseáticos não eram mercadores germânicos; eles eram uma corporação de oligarcas comerciais, sediados em diversas cidades do mar do Norte e do Báltico. Longe de 'nacionalizarem' a vida econômica germânica, a Hansa deliberadamente isolava o interior do comércio. O comércio de Antuérpia ou Hamburgo, Veneza ou Lyon não era, de forma alguma, holandês ou germânico, italiano ou francês. (POLANYI, 1944:77)

Quando e como surge, então, o mercado nacional? Ele não é uma conseqüência direta, "natural", dos mercados já existentes? Por ser considerado um mercado 
intermediário, que não se desenvolve espontaneamente a partir dos mercados anteriores, tanto locais quanto à longa distância?

É com a formação dos Estados territoriais que chega seu processo correlato: a formação dos mercados nacionais. São aqueles, e não as cidades-estados, que facilitam a existência de um sistema econômico integrado em grandes unidades territoriais. Criam-se superfícies mercantis contínuas e delimitadas.

Talvez seja a contiguiidade, como atributo central do Estado territorial, uma das escolhas políticas de maior influência na história dos mercados. Para Camille Vallaux (1914: 309), "não se registra transformação tão profunda nem tão rica em consequiências, na história do globo, como o advento da contiguidade sem interrupção dos Estados".

Longe de ser uma evolução espontânea, trata-se de um processo de caráter basicamente político, que acarreta oposições e confrontos:

O mercado nacional, finalmente, é uma rede de malhas irregulares, freqüentemente construida a despeito de tudo: a despeito das cidades demasiado poderosas que têm sua politica própria, das províncias que recusam a centralização, das intervenções estrangeiras que acarretam rupturas e brechas, sem contar interesses divergentes da produfão e das trocas - pensemos nos conflitos da França entre portos atlânticos e portos mediterrânicos, entre interior e frente marítima. A despeito também dos enclaves de auto-suficiência que ninguém controla. (BRAUDEL, 1986: 265)

Podemos perguntar-nos, com Richard Rosecrance (1986), por que cidades como Veneza, Gênova e os membros da Liga Hanseática, que acumularam grandes riquezas comerciando e navegando por diferentes lugares do mundo, não formaram uma confederação de pequenos Estados mantida por um comércio oceânico? Por que, então, não surgiu uma concepção linear da organização estatal em lugar daquela baseada na superfície, na contigüidade, fundamento do Estado territorial?

As cidades-estado enredaram-se em conflitos de competências entre elas mesmas; o comércio não era completamente livre nem carecia de obstáculos, e conseqüientemente cada uma delas desejava reservar-se determinadas zonas para monopolizar seu comércio ou para dispor do domínio sobre determinadas fontes de produtos-chave. As cidades mais poderosas não raro tratavam de conquistar suas vizinhas mais fracas para suprimir um mercado rival:

(...) uma das razões pelas que não se estabeleceu ao início da Idade Moderna uma organização linear dos paises foi porque as cidades-Estado comerciais mantiveram entre elas uma guerra contínua e não foram capazes de estabelecer um esquema estável e duradouro de cooperaf̧ão. (ROSECRANCE, 1986: 91)

A base puramente local das cidades muradas, a despeito do comércio a longa distância que elas exerciam, é apontada por Mumford como uma de suas fraquezas: 
Para que exercessem controle monopolístico dentro de seus muros, era essencial que fossem capazes de governar o reino também fora deles: isso implicava o hábito de harmonizar seus próprios interesses com os do campo e, com o tempo, de provocar uma organização federada de regiões em torno de cidades. Contudo, as normas reais adotadas pelas mais poderosas e dinâmicas cidades medievais eram agressivamente encaminhadas em direção oposta. (MUMFORD, 1961:366)

Na Europa ocidental o comércio interno ou nacional foi criado, sobretudo, por uma vontade política. O Estado, que lentamente ia adquirindo seu caráter territorial, começou a se projetar como o instrumento da "nacionalização" do mercado e criador do comércio interno. Por sua vez, e em contraste com o comércio externo e o local:

(...) o comércio interno é essencialmente competititivo. Além das trocas complementares, ele inclui um número muito maior de trocas nas quais as mercadorias similares, de fontes diferentes, são oferecidas em competição umas com as outras. Assim, somente com a emergência do comércio interno ou nacional é que a competição tende a ser aceita como princípio geral de comércio. (POLANYI, 1944: 74)

Podemos pensar que à divisão espacial do trabalho e à especialização produtiva - base dos mercados locais e externos - soma-se uma competitividade entre os lugares, trazida com a criação dos mercados nacionais. Os limites que impõe o Estado territorial contribuiriam, também, para este processo.

Pouco a pouco foi-se estabelecendo, entre os séculos XVI e XVIII, a correspondência entre estruturas territoriais, políticas e econômicas em bases nacionais. "A soberania territorial tornou-se, no século XVII, e continua a ser, a base de um certo status de igualdade entre os Estados, como a que deve existir entre os soberanos" (GOTTMAN, 1973: 54). E esse processo foi acompanhado, de forma crescente, pela implementação das idéias e das práticas do mercantilismo.

\section{O mercantilismo, uma estratégia política}

A criação de ambientes geográficos contínuos de administração política dentro de uma estrutura centralizada é a base do Estado territorial. E como resultado deste novo sistema interestatal surge uma preocupação pela política econômica numa escala superior à das cidades. "Em um sistema de Estados competitivos, a segurança requer algo mais do que o reconhecimento da soberania; requer estar no mesmo nível que os Estados vizinhos em termos econômicos. Por esse motivo surgiu o mercantilismo" (TAYLOR, 1985:147).

A unificação de territórios fragmentados pelo particularismo feudal e municipal permitiu à nova política estatal mercantilista contar com os recursos de todo o ter- 
Para que exercessem controle monopolístico dentro de seus muros, era essencial que fossem capazes de governar o reino também fora deles: isso implicava o hábito de harmonizar seus próprios interesses com os do campo e, com o tempo, de provocar uma organização federada de regiões em torno de cidades. Contudo, as normas reais adotadas pelas mais poderosas e dinâmicas cidades medievais eram agressivamente encaminhadas em direção oposta. (MUMFORD, 1961:366)

Na Europa ocidental o comércio interno ou nacional foi criado, sobretudo, por uma vontade política. O Estado, que lentamente ia adquirindo seu caráter territorial, começou a se projetar como o instrumento da "nacionalização" do mercado e criador do comércio interno. Por sua vez, e em contraste com o comércio externo e o local:

(...) o comércio interno é essencialmente competititivo. Além das trocas complementares, ele inclui um número muito maior de trocas nas quais as mercadorias similares, de fontes diferentes, são oferecidas em competição umas com as outras. Assim, somente com a emergência do comércio interno ou nacional é que a competição tende a ser aceita como princípio geral de comércio. (POLANYI, 1944: 74)

Podemos pensar que à divisão espacial do trabalho e à especialização produtiva - base dos mercados locais e externos - soma-se uma competitividade entre os lugares, trazida com a criação dos mercados nacionais. Os limites que impõe o Estado territorial contribuiriam, também, para este processo.

Pouco a pouco foi-se estabelecendo, entre os séculos XVI e XVIII, a correspondência entre estruturas territoriais, políticas e econômicas em bases nacionais. "A soberania territorial tornou-se, no século XVII, e continua a ser, a base de um certo status de igualdade entre os Estados, como a que deve existir entre os soberanos" (GOTTMAN, 1973: 54). E esse processo foi acompanhado, de forma crescente, pela implementação das idéias e das práticas do mercantilismo.

\section{O mercantilismo, uma estratégia política}

A criação de ambientes geográficos contínuos de administração política dentro de uma estrutura centralizada é a base do Estado territorial. E como resultado deste novo sistema interestatal surge uma preocupação pela política econômica numa escala superior à das cidades. "Em um sistema de Estados competitivos, a segurança requer algo mais do que o reconhecimento da soberania; requer estar no mesmo nível que os Estados vizinhos em termos econômicos. Por esse motivo surgiu o mercantilismo" (TAYLOR, 1985:147).

A unificação de territórios fragmentados pelo particularismo feudal e municipal permitiu à nova política estatal mercantilista contar com os recursos de todo o ter- 
ritório nacional para os objetivos de poder nos assuntos externos. Por seu lado, os recursos privados disponíveis sob a forma de dinheiro acumulado também contribuíram para o processo de unificação. "Uma economia volumosa, amplamente estendida no espaço, 'territorializada' e suficientemente coerente para que os governos possam de certo modo modelá-la e manobrá-la. O mercantilismo é justamente a tomada de consciência dessa possibilidade de manobrar o conjunto da economia de um país, ou seja, resumindo, a busca, já, do mercado nacional" (BRAUDEL, 1986: 271).

Os Estados territoriais, ao mesmo tempo em que liberaram o comércio dos limites da cidade privilegiada, reforçaram sua intervenção, criando normas estritas para a vida econômica, só que agora em escala nacional e não mais apenas municipal. “A 'libertação' do comércio levada a efeito pelo mercantilismo apenas liberou o comércio do particularismo, porém, ao mesmo tempo, ampliou o escopo da regulamentação" (POLANYI, 1944:80). Assim, o mercantilismo foi a transferência das políticas mercantis da cidade comercial para o Estado territorial - "em outras palavras, aumentou-se a escala das restrições territoriais sobre o comércio até se converter em uma arma fundamental para criar Estados" (TAYLOR, 1985:147).

As cidades que ofereciam o novo privilégio municipal do livre comércio e do livre depósito de bens, sem taxa de entrada, foram criando um ambiente cada vez mais favorável para encorajar novos negócios. O que o capitalista entendia por liberdade era a fuga à proteção, à regulamentação, aos limites municipais, às obrigações caritativas. Segundo Mumford (1961:450), "durante a Idade Média, " liberdade' significava liberdade em relação às restrições feudais, liberdade para as atividades corporativas da municipalidade, a guilda, a ordem religiosa. Nas novas cidades de comércio, liberdade significava liberdade das restrições municipais: liberdade para o investimento privado, para o lucro privado e para a acumulação privada". O novo Estado absolutista foi chamado a quebrar esse particularismo, derrubando as barreiras que separavam o comércio local do de longa distância e abrindo assim o caminho para a formação do mercado interno.

A partir do século XVI, mudou o centro de gravidade do mundo ocidental do Mediterrâneo para as costas do Atlântico. Pode-se falar da existência de uma sociedade mercantil, na qual a produção já não se restringia às cidades e ficou sob a liderança organizadora do mercador. Com efeito, a indústria doméstica era provida de matérias-primas pelo mercador, que controlava o processo de produção como uma empresa puramente comercial:

Ele conhecia o mercado, o volume e a qualidade da demanda, e podia se encarregar também dos suprimentos que, incidentalmente, se constituíam apenas em lã, tinturas e, às vezes, molduras ou teares usados pela indústria doméstica. Se não houvesse suprimentos o aldeão era o mais prejudicado, pois perdia seu emprego durante algum tempo. O caso não envolvia nenhuma fábrica dispendiosa e o mercador não incorria. em risco sério ao assumir a responsabilidade da produção (POLANYI, 1944:86) 
Assim, até o final do século XVIII a produção industrial na Europa ocidental era quase um acessório do comércio. A preocupação principal do pensamento mercantilista, que girava em torno da circulação de mercadorias, era a criação de uma balança comercial favorável e o acúmulo de divisas em metais preciosos pelo Estado territorial. Defendia, para isso, um comércio exterior de caráter protecionista. No entanto, além de afirmar sua teoria em termos de um balanço comercial favorável, os mercantilistas achavam-se igualmente preocupados com as vantagens das relações favoráveis de troca, baseadas no princípio de "comprar barato e vender caro". Daí ser frequiente, por um lado, sua recomendação de exportação às manufaturas e, por outro, sua condenação às importações ao que não fosse matéria-prima e mercadoria acabada, destinada ao consumo de luxo (como o vinho, que servia às necessidades das classes superiores).

Além de uma doutrina, o mercantilismo implicou uma política estatal de nacionalismo econômico desenvolvida na prática por ministros, administradores e comerciantes que "concebiam as condições de oferta e procura como muito moldáveis em face da pressão política" (DOBB, 1963:258). Assim, parecia natural que o objetivo da intervenção estatal fosse modificar as condições sobre as quais repousavam as relações de troca para vantagem própria, ou seja, modelar o mercado conforme o interesse próprio.

Os mercantilistas deram muita atenção ao uso do território. Durante o século XVII, vários autores introduziram o debate sobre a competição entre regiões dentro do território nacional (sempre a partir da premissa a favor do comércio internacional para desenvolver as economias nacionais e regionais). Dentre eles destacam-se Thomas Mun, Josiah Child e William Temple, na Inglaterra, e Antoine de Montchrétien, na França. Este último foi influenciado fundamentalmente pela obra de Jean Bodin, desenvolvida no século anterior e que descreve a diversidade e a complementaridade das partes do mundo como origem da divisão do trabalho e do comércio internacional.

Nesse contexto, Bernhard Varenius publica sua Geografia Generalis (1650), uma tentativa pioneira de esboçar as leis gerais da geografia do fenômeno físico. William Petty escreve diversos trabalhos sobre a distribuição e o crescimento da população, os recursos e as cidades. Vauban, em torno de 1700, apresenta um memorando a Luís XIV propondo o estabelecimento de um imposto único, proporcional à renda de cada indivíduo e pago por todos. Ele sugere que, para impor o imposto geral e planejar políticas econômicas, é necessário em primeiro lugar reconhecer e estudar completamente todo o território e a população que nele habita.

Referindo-se a esses autores do século XVII, Gottman (1973:64) comenta que:

A consciência nacional desenvolvida nessa época fez os estudiosos compreenderem que, na competição pelo progresso, as pessoas eram decerto o principal fator, tanto na quantidade como na qualidade, mas que o uso e a organização de seu território era'o seguinte fator em importância, e um fator que a política nacional não podia dar-se ao 
luxo de ignorar. E acrescenta que ao fim desse século tornou-se uso estabelecido estudar a geografia populacional e econômica de um território antes de decidir quaisquer novas políticas ou regras para governá-lo, e comparar as observações desse estudo com dados similares, na medida do possível, aos de outras áreas do mesmo tipo.

Além das idéias e dos trabalhos publicados, houve diferentes experiências mercantilistas; sua aplicação variava conforme a situação do país, seus recursos e o modelo de governo vigente. O exemplo mais eloqüente é talvez o de Colbert, ministro de Luís XIV, engenheiro, geógrafo, economista, estrategista e estadista:

Colbert equipa o Estado com redes rodoviárias efluviais que, apesar da verticalidade mantida nas relações com o centro, permitem uma acumulação das trocas interprovinciais e um crescimento da divisão inter-regional do trabalho. Esse esforço, voltado para a infra-estrutura material das trocas, pressupunha primeiramente o contorno do valor jurisdicional dos limites, obtido por meios fiscais e jurídicos consagrados à redução dos pedágios. (ALLIÉS, 1980: 76-77)

Isso era, segundo Paul Alliés, encorajar os fluxos comerciais a se intensificar, dando-lhes primeiro a garantia estatal do trânsito, a inscrever-se em seguida num espaço que nunca tinha sido tão fechado. Era também uma política que visava a pôr em relação estruturada as trocas de longa distância e as comunicações comerciais internas, cujo descompasso era uma característica do período. Ela produzia seus próprios equipamentos dando um conteúdo ativo à fronteira alfandegária. Esta era um instrumento privilegiado de unificação do espaço mais sensível naquele momento, o espaço atravessado pelas redes mais densas, traçado pelos movimentos do capital comercial. Era a sua conexão com as instituições estatais, com as operações de saneamento das zonas fronteiras que definia o exato processo de encerramento do espaço num sentido capitalista.

Pedágios e alfândegas coincidem agora com os limites dos territórios nacionais, expressão material da separação interna-externa dos espaços.

A consolidação de um mundo mercantilista no século XVII está diretamente relacionada com as atividades coloniais dos Estados imperiais. Holanda, França e Inglaterra, que se somaram à ação imperial de Espanha e Portugal, em diferentes momentos e com estratégias variadas, foram expandindo suas áreas de influência política e econômica além do centro. Trata-se da configuração do "imperialismo formal", um método político para criar novas zonas de produção econômica na economia-mundo que permite assegurar a integração de regiões exteriores na divisão do trabalho dessa economia (TAYLOR, 1985). O mercantilismo partia da premissa de que cada Estado tinha de apoderar-se da maior parte do mercado mundial que fosse possível, desenvolvendo sua indústria e seu comércio a expensas de outros Estados. 
As companhias de comércio exterior são instituições características desse processo de expansão dos Estados imperiais no período mercantilista. Organizadas por comerciantes e governos europeus para controlar as relações de troca entre a metrópole e as colônias, funcionavam a partir de práticas monopolistas garantidas pelo protecionismo estatal. Além do monopólio comercial, muitas delas conseguiram a prerrogativa de conquistar territórios e administrá-los. A entrada para as companhias geralmente era fechada, sendo possível apenas por patrimônio, aprendizado (com um número limitado de aprendizes) ou pela compra, enquanto os varejistas, lojistas ou artesãos em geral se viam explicitamente excluídos. "As grandes companhias comerciais não eram diferentes de seus precursores genoveses, e podem ser descritas como empreendimentos conquistadores semiguerreiros, às quais direitos soberanos tinham sido concedidos pelas forças do Estado" (DOBB, 1963: 257).

Entre os séculos XV e XVIII tomou forma na Europa uma nova economia, o capitalismo comercial, e uma nova estrutura política, principalmente a do absolutismo ou da oligarquia centralizada, geralmente personificada num Estado territorial. É a partir desse momento que podemos, talvez, pensar na convergência histórica das três categorias: território, mercado e Estado.

\section{Território, mercado e Estado}

A proposta de Gottman associa o surgimento do Estado territorial não apenas ao problema da segurança mas também ao tema da oportunidade. O poder político, no mesmo tempo que o poder econômico, está associado ao território. É o pensamento, sobretudo, de Vauban que o leva a essa leitura:

Na forma tripartide do Estado moderno, o território é o constante essencial que liga as pessoas à estrutura governamental unificada. As relações econômicas entre pessoas e território de um lado, e entre governo e território do outro, irão variar constantemente segundo um conjunto multifacetado de fatores, entre os quais a tecnologia disponivel, assim como o conhecimento disponível sobre o território e os países vizinhos, será o mais importante. Mas o território, como vínculo indispensável, permanece constante e essencial. Assim é por razões de segurança-política e militar -, mas também por razões econômicas $e$, portanto, para a felicidade e a oportunidade das pessoas. (GOTTMAN, 1973: 60)

O contexto histórico dos séculos XVI e XVII encoraja os pensadores e administradores a definir novos parâmetros de ação. O sistema interestatal moderno que surge nessa época oferece uma raison d'état alternativa que gira em torno da economia em lugar da raison d'état tradicional, que se apoiava na política, na guerra e na glória do rei. Esse processo vincula-se diretamente à hegemonia holandesa. A 
Holanda era um Estado pouco comum para aquele momento, pois estava dirigido por comerciantes e para comerciantes. Afirma Taylor:

Em vez de ver o incremento do novo território como um aumento da glória política, ele poderia ser visto através de lentes de custo-benefício econômico. Dessa perspectiva, apesar dos despojos e recompensas, a guerra poderia ser vista como destruidora da prosperidade econômica. Daí o seu estado pacífico e a guerra defensiva. Em vez da sua raison d'état, a razão do comerciante: perseguir políticas que ajudem o comércio e a produção com o fim último de promover a acumulação de capital. $O$ Estado devia tornar-se um receptáculo de riqueza, não guerrear melhor, mas criar mais riqueza. (TAYLOR, 1994:154)

Uma raison d'état não suprime a outra. Elas coexistem - ainda hoje -, ora predominando uma, ora a outra, conforme o rincão do planeta e o período histórico. Conforme, sobretudo, a forma de construir a hegemonia que cada império escolha.

Perante o sucesso do Estado holandês, os mercantilistas ingleses e franceses compreendem que é necessário fazer uma política econômica mais complexa do que administrar a própria fazenda. Por isso Gottman insiste em que somente no século XVII o pensamento econômico e político na Europa começa a perceber o significado do território:

O território não tem valor econômico em si mesmo; ele gera a riqueza de várias e diferentes maneiras em conseqüência dos usos que dele fazem os seus habitantes. [...] Todavia, pessoas e territórios não são separáveis na produção de bens e serviços: a produção há de ocorrer em algum lugar, e o local ou a área é um dos fatores condicionantes do processo econômico. O território onde o processo se desenvolve deve estar sob um regime político, dentro de um dado sistema de leis e num determinado lugar com respeito aos meios de transporte e aos mercados. O território, sendo habitat das pessoas, é o receptáculo de suas atividades econômicas. (GOTTMAN, 1973:57)

A consideração do território como um assunto importante na filosofia da organização econômica coincide não apenas com o crescimento dos recursos, devido ao desenvolvimento em larga escala do comércio, da indústria e das atividades bancárias, mas também com uma rápida expansão sobre as novas terras que estão sendo apropriadas fora da Europa. Há uma emergência e expansão das relações capitalistas de produção e há, sobretudo, uma entrada em cena dos territórios coloniais. Eles estão associados, em grande medida, à função de oportunidade que Gottman atribui ao território.

\section{Os territórios coloniais}

Talvez possamos continuar nossa réflexão com Dobb (1963:257) quando ele diz que "o Sistema Mercantil foi um sistema de exploração regulamentada pelo Estado 
e executada através do comércio, que desempenhou um papel importantíssimo na adolescência da indústria capitalista, sendo essencialmente a política econômica de uma era de acumulação primitiva". Como se explicam os territórios coloniais nesse sistema?

A colonização da época mercantilista se desenvolveu promovendo a acumulação primitiva de capitais nas economias centrais européias. É o regime do "exclusivo" metropolitano que se constitui no mecanismo básico desse processo:

Reservando-se a exclusividade do comércio com o Ultramar, as metrópoles européias na realidade organizavam um quadro institucional de relações tendentes a promover necessariamente um estímulo à acumulação primitiva de capital na economia metropolitana a expensas das economias periféricas coloniais. [...] $O$ comércio foi de fato o nervo da colonização do Antigo Regime, isto é, para incrementar as atividades mercantis processava-se a ocupação, povoamento e valorização das novas áreas" (NOVAIS, 1983:72).

Registrado o caráter subordinado da colônia, podemos observar o modo como território e mercado se associam desde a gênese desse processo histórico. Tanto a procura do lucro mercantil quanto a necessidade de domínio da terra são objetivos concomitantes em qualquer empreendimento colonial. "As medidas não só de coação, aplicadas ao comércio colonial para que este servisse principalmente às necessidades do país metropolitano, mas também de controle da produção colonial, tornaram-se uma preocupação especial da política no final do século XVII e primeira metade do XVIII" (DOBB, 1963:252). Tanto coação quanto controle implicam subordinação dos recursos e da população local.

A intenção do lucro só se realiza com o acesso àquilo que os lugares oferecem:

A força do valor contido - o valor do espaço - exprime-se tanto na riqueza natural depositada em dado lugar quanto no trabalho morto acumulado in situ; e ainda no contingente populacional presente em cada região. $O$ espaço do colonizador contém recursos naturais, heranças entesouradas e pessoas agrupadas; estes são os principais vetores da atração. (MORAES, 2000:272)

O processo de colonização também nos permite observar a maneira como normas e fluxos se constituem em elementos estruturadores dos territórios coloniais:

As relações coloniais podem, na realidade, ser apreendidas em dois niveis: primeiro, na extensa legislação ultramarina das várias potências colonizadoras (Portugal, Espanha, Holanda, França, Inglaterra); segundo, no movimento concreto de circulação de umas para outras, isto é, no comércio que faziam entre si, e nas vinculações políticoadministrativas que envolviam. (NOVAIS, 1995:58) 
Por um lado, as normas legais - aquele imenso corpo da legislação colonial que cristaliza os objetivos dos Estados europeus - procuram disciplinar a vida política e econômica dos territórios coloniais e, portanto, definir sua organização. Destacam-se, sobretudo, as normas rígidas de comércio - que iam da criação de monopólios até o estabelecimento dos preços e cotas de importação e de exportação. Por outro, os fluxos de mercadorias, de ordens e de idéias que circulam entre metrópole e colônia definem uma dinâmica territorial. As redes que se criam são reguladas fundamentalmente pelo país colonizador.

Embora a projeção do sistema colonial sobre os territórios dependentes tome formas diversas, existe, em todos eles, uma forte tendência à concentração de riquezas. Na realidade, esta condição é necessária para garantir o funcionamento do sistema:

[...] é o fato de a parcela (menor) que permanece na colônia se concentrar na pequena camada senhorial que permite o contínuo funcionamento da exploração colonial. De fato, é essa concentração de renda que faz com que, apesar dos mecanismos do regime de comércio transferirem o maior quinhão para a burguesia européia, os colonossenhores possam manter a continuidade do processo produtivo, e mesmo levar uma vida faustosa; da mesma forma, e ainda dentro da mecânica do sistema, têm os mesmos colonos recursos para importar os produtos da economia européia. (NOVAIS, 1995:107)

Assim, a renda na sua parte mais significativa cria-se nas exportações e se consome nas importações, transferindo para a metrópole os lucros do exclusivo.

As feitorias são, talvez, um dos primeiros exemplos da associação - lenta mas estável - entre território e mercado na colônia. Antonio Carlos Robert Moraes assinala que, além de ser inicialmente local de armazenagem e embarque do pau-brasil:

(...) a feitoria foi, ademais, um laboratório de conhecimento da terra, de seus produtos $e$ de seus habitantes. Um locus de aclimatação e marco de soberania, enfim, uma base de ocupação cuja edificação revelaria um intuito protocolonizador [...]. A feitoria representou, assim, um local de trocas não apenas econômicas mas também culturais, $e$ a importância destas últimas não pode ser minimizada quando se busca entender a instalação lusitana nas terras americanas. (MORAES, 2000:293)

À medida que avança o processo colonizador, esses núcleos litorâneos, assim como outros tipos de assentamentos gerados no solo americano, foram-se transformando em projetos econômicos mais complexos e desenhando padrões espaciais também mais complexos. Vai-se gerando uma dinâmica interna, com ativos circuitos da produção que respondem a interesses locais, além do intercâmbio metropolitano (MORAES, 2000). 
O processo que progressivamente associa o território ao mercado na história da América Latina se desenvolve ao mesmo tempo em que, na Europa, se expande o capitalismo e se consolida o sistema interestatal moderno. Isto é, os Estados territoriais europeus apóiam-se na consolidação de um sistema econômico que se integra em unidades nacionais através da formação do mercado interno. Na América Latina, por sua vez, a convergência entre território, mercado e Estado (nos moldes europeus) dar-se-á somente séculos mais tarde, com a irrupção dos processos de independência política e a formação dos Estados nacionais. Essa convergência se definirá em termos de um "fora" - marcado pela condição periférica da América Latina - e de um "dentro" - marcado pela concentração (social e regional) de riquezas.

TERRITÓRIO, MERCADO E ESTADO:

UMA CONVERGÊNCIA HISTÓRICA

Resumo: Este artigo busca questionar a forma em que a convergência entre território, mercado e Estado se desenvolveu no continente europeu até chegar aos territórios coloniais, especialmente a América Latina.

Palavras-chave: Território, Mercado, Estado, Capitalismo.

\section{TERRITORY, MARKET AND STATE: A HISTORICAL CONVERGENCE}

Abstract: This paper aims to discuss the way by which convergence among territory, market and State have been developed in Europe, until reach colonial territories, specially Latin America.

Keywords: Territory, Market, State, Capitalism.

\section{BIBLIOGRAFIA}

ALLIÈS, Paul (1980). L'Invention du territoire. Grenoble: Presses Universitaires de Grenoble.

ARROYO, Mónica. (2001) Território nacional e mercado externo. Uma leitura do Brasil na virada do século XX. Tese de doutorado, Departamento de Geografia da Faculdade de Filosofia, Letras e Ciências Humanas da Universidade de São Paulo.

BRAUDEL, Fernand (1996[1979]). Civilização material, economia e capitalismo. Sécs. XV-XVIII, vol. 2, "Os jogos das trocas". São Paulo: Martins Fontes. (1996[1986]). Civilização material, economia e capitalismo. Séculos XV-XVIII. vol. 3, "O tempo do mundo", São Paulo: Martins Fontes.

CORR A, Roberto Lobato (1997). Trajetórias geográficas. Bertrand Brasil: Rio de Janeiro.

COSTA, Wanderley Messias (1992). Geografia política e geopolítica: discursos sobre o território e o poder. São Paulo: Hucitec. 
DOBB, Maurice (1977[1963]). A evolução do capitalismo. Rio de Janeiro: Zahar Editores.

GOTTMAN, Jean (1952). La Politique des États et leur Géographie. Paris: Librairie Armand Colin.

(1973). The significance of territory. Charlottesville: The University of Virginia Press, Charlottesville.

MORAES, Antonio Carlos Robert (2000). Bases da formação territorial do Brasil. O território colonial brasileiro no "longo" século XVI. São Paulo: Hucitec.

MUMFORD, Lewis (1982[1961]). A cidade na História: suas origens, desenvolvimento e perspectivas. São Paulo: Martins Fontes.

NOVAIS, Fernando (1995). Portugal e Brasil na crise do Antigo Sistema Colonial (1777 - 1808). São Paulo: Hucitec.

PIRENNE, Henri (1966[1933]). História econômica e social da Idade Média. São Paulo: Editora Mestre Jou.

(1962[1925]). As cidades da Idade Média. Lisboa: Publicações Europa-América, Lisboa.

POLANYI, Karl (1980[1944]). A grande transformação. As origens da nossa época. Rio de Janeiro: Editora Campus.

ROSECRANCE, Richard (1987). La expansión en el Estado comercial. Comercio y conquista en el mundo moderno. Madrid: Alianza.

SANTOS, Milton (1978). Por uma geografia nova. São Paulo: Hucitec.

TAYLOR, Peter (1994[1985]). Geografía política. Economía-mundo, Estadonación y localidad. Madrid: Trama Editorial.

(1994). "The state as container: territoriality in the modern worldsystem", in Progress in human geography, 18 (2), pp. 151-162.

VALLAUX, Camille (1914). El Suelo y el Estado. Madrid: Daniel Jorro Editor.

WALLERSTEIN, Immanuel (1984[1980]). El moderno sistema mundial II. El mercantilismo y la consolidación de la economía-mundo europea, 16001750. Madrid: Siglo Veintiuno Editores. 